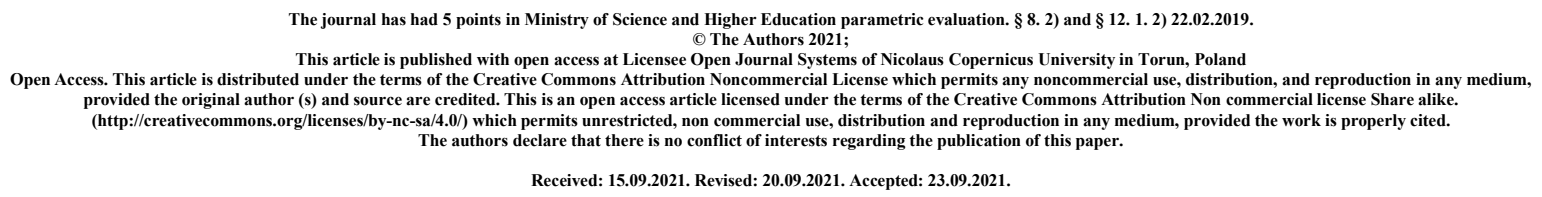

\title{
REPORTS OF RECENT YEARS ON PHYSIOTHERAPY AND THE HEALTH OF CHILDREN
}

mgr Piotr Jaworski, e-mail: jawor19 94@,o2.pl, ORCID ID: https://orcid.org/0000-00022893-3705, Collegium Medicum, Uniwersytet Jana Kochanowskiego w Kielcach

\begin{abstract}
The physiotherapy process in children is specific and requires much more patience and understanding than in adults. Working with a child is not only related to the physiotherapy of a small patient, but also in a very good cooperation between the parent-physiotherapist. The paper presents selected issues of children's therapy in the light of research papers published in renowned scientific journals dealing with medical issues.
\end{abstract}

Key words: Physiotherapy, children, therapy, prophylaxis

\section{INTRODUCTION}

Paediatric physiotherapy is an extremely important branch of physiotherapy. A physiotherapist dealing with young patients should be full of patience but also understanding of pediatric patients. In addition, he or she should have completed a number of specialized physiotherapy training courses in pediatric therapy. It is important to remember that even at an early stage, a properly started physiotherapy process can help improve future outcomes in therapy. What is more, current physiotherapy has a number of modern diagnostic methods that make it possible to detect the first disorders much earlier in children. In addition, a very 
large number of publications examining the relationships between specific variables promotes adequate patient information on prevention in given disease entities.

The aim of this study is to analyze the research published in the journals Fizjoterapia polska and Ortopedia Traumatologia Rehabilitacja and concerns the effectiveness of physiotherapy in children and the factors that may affect its progress.

\section{MATERIAL AND METHODS}

The literature analysis included a methodical review of scientific journals: Physiotherapy Poland and Orthopedics Traumatology Rehabilitation. Scientific publications that dealt with physiotherapy in paediatrics and assessed the current health status of the studygroup were qualified for the review.

We analyzed 13 scientific publications on physiotherapy in children, which are in peer-reviewed scientific journals and were published within the last 5 years. The analyzed material concerned issues related to various fields of medicine.

\section{DISCUSSION}

Małgorzata Kilon et al. in their study „Ocena stanu funkcjonalnego dzieci z mózgowym porażeniem dziecięcym przy użyciu wybranych skal i testów” examined a group of 33 children ranging in age from 4 to 18 years. Sixteen children showed no verbal-logical contact. One of the main criteria for inclusion in the study was the diagnosis of cerebral palsy. The authors used a questionnaire of the author's questionnaire and 3 scales to assess motor skills in order to realize the topic of the study. The GMFM scale - Gross Motor Function Measure - was used to assess gross motor function (it contains 88 questions which concern observations of a child in the following five categories: lying and turning, sitting, crawling and kneeling, standing and walking, running and jumping) and GMFCS - Gross Motor Function Classification System (the scale is based on the assessment of functional status and the need for orthopedic supplies such as a walker, crutches or wheelchairs to assist in mobility), while for the assessment of fine motor skills MACS - Manual Ability Classification System scale was used (it is based on the assessment of manual skills of the subject, the study is conducted on the basis of an interview The test is based on an interview with the parent/guardian). The results of the study by M. Kilon et al. showed that children who had better verbal-logical contact had better results when assessed with scales [Kilon 2018, 4, 8693].

Balancing is a big problem in children with cerebral palsy. Emilia Matusiak- 
Wieczorek et al. in their study „Wpływ hipoterapii na zdolność utrzymywania równowagi w pozycji siedzącej wśród dzieci z mózgowym porażeniem” examined a group of 39 children aged 6 to 12 years. Patients with a diagnosis of spastic diplegia or hemiplegia classified as GMFCS level I/II were eligible for the study. The subjects were randomly divided into two groups. The study group consisted of 19 patients who were subjected to hippotherapy sessions for 12 weeks, which took place once a week and lasted 30 minutes, and a control group of 20 patients. In the study, the authors used the SAS scale, which assesses the control of body posture and balance while sitting. The results of E. Matusiak-Wieczorek's study showed a positive effect of hippotherapy on improving balance and posture. The authors observed that trunk positioning, head positioning and control of arm function improved the most, while control of foot function improved somewhat less [Matusiak-Wieczorek 2016, 2, 165-175]. Virtual reality is an increasingly used element of modern comprehensive physiotherapy. Emilia Wysoczańska et al. in their paper „Wpływ terapii z wykorzystaniem nowoczesnych technologii na aktywność i wytrzymałość dzieci z mózgowym porażeniem dziecięcym" examined a group of 14 children between the ages of 8 and 12 who had been diagnosed with cerebral palsy. The entire group was subjected to standard traditional therapy, which included strengthening weakened muscles, mobilization of joints of upper and lower limbs, coordination exercises, balance exercises, functional exercises, gait re-education, and the use of NDT (neurodevelopmental treatment) Bobath and PNF (Proprioceptive Neuromuscular Facilitation). In addition, virtual reality therapy was used. It lasted 40 minutes and was conducted for eight weeks, twice a week. During its duration, the authors performed three control measurements to verify the impact of therapy, and then after 4 months after the completion of therapy, the fourth measurement was performed. The results of the study by E. Wysoczanska et al. prove the positive impact of using virtual reality therapy in children with cerebral palsy. However, after a two-month break from its use was observed a decrease in the results achieved thanks to it [Wysoczańska 2017, 2, 100-111].

It is worth noting the study by Włodzisław Kuliński et al. in the paper „Kinezyterapia w mózgowym porażeniu dziecięcym - aspekty kliniczne". The authors conducted a study on a group of 20 subjects (12 females, 8 males) in the age range of 20-60 years. Individuals qualified for the study were patients diagnosed with cerebral palsy. To conduct the study, the authors used a survey questionnaire. It covered aspects related to the life and functioning of the respondents and the assessment of the physiotherapy provided. The results of the study by Kuliński et al. confirm that kinesitherapy has a very important role in the treatment of people with cerebral palsy. It contributes to an increase in physical condition and improvement in 
functioning in daily life. The authors report that it is very important for the patient to receive support from the immediate family [Kuliński 2019, 3, 106-117]. The Vojta method is very often used in the therapy of children with central nervous coordination disorders. Katarzyna Balewska-Juras et al. in work „Ocena wyników neurokinezjologicznego usprawniania metodą odruchowej lokomocji według Vojty, dzieci z zaburzeniami centralnej koordynacji nerwowej" examined a group of 45 children (16 girls, 29 boys) aged between 1 and 10 months. The subjects were divided into two groups. In the first group the therapy with the Vojta method started between 2 and 4 months of life (32 patients), whereas in the second group between 5 and 10 months of life (13 patients). Central neuromuscular coordination disorders were diagnosed in all subjects. In order to evaluate the subjects, the authors performed seven positioning reactions according to the Vojta method, which were then analyzed and the Munich Functional Developmental Diagnosis. The diagnostics took place several times - before starting the therapy and at intervals of 4-6 weeks during the therapy. The therapy lasted The therapy lasted from 1 to 11 months, depending on the effects of the therapy taking into account the neurological state and spontaneous motor skills. The results of the study by K. Balewska-Juras et al. prove the effectiveness of the Vojta therapy on the improvement of spontaneous motor activity and neurological condition in children with impaired central nervous coordination [Balewska-Juras 2015, 4, 32-41].

Another paper is by Alicja Salwach et al. „Ocena równowagi u dzieci ze spektrum zaburzeń autystycznych w wieku 5-7 lat”. The authors studied a group of 30 children diagnosed with autism spectrum disorders. The group consisted of 22 boys and 9 girls, ranging in age from 5 to 7 years. The authors used a modified Scoring for Fullerton Advanced Balance Scale test to assess balance. The original version of the test consists of 10 tasks, which are scored on a scale from 0 to 4 . In the study we used a standing test with feet together (eyes closed), a test consisting in a 360 degree rotation to the right and left, a tandem gait test, a standing test on one leg (right and left), and a standing test with open eyes on an unstable surface [Salwach 2019, 1, 38-45].

Marek Woszczak et al. in their study „Ocena zróżnicowania poziomu otłuszczenia ciała osób uprawiających piłkę ręczną klasach I, II i III gimnazjum w zależności od poziomu ich wytrenowania i sprawności fizycznej" examined a group of 83 people attending a gymnasium. The authors used the International Test of Physical Fitness (which consists of 6 tests: jumping from a distance, endurance run, hand strength measurement through a dynamometer, hang on a bar, sit-ups and forward bending) and determined the following measurements: BMI, Slenderness Index (determines the level of body slenderness), Rohrer 
Index (determines the type of body build) and Fat Distribution Index (determines the level of abdominal obesity). Skin-fat fold measurements were also performed. The results of the study by M. Woszczak et al. show that the skinfold measurement increases with age and the level of physical fitness increases with age [Woszczak 2017, 4, 84-105]. Another study taking into account body mass is the one by Anna Kogut et al. „Badanie wpływu masy ciała oraz aktywności fizycznej na jakość życia młodzieży gimnazjalnej”. The authors studied a group of 57 subjects ( 29 girls, 28 boys) between the ages of 12 and 15 . For the study the authors used a survey questionnaire on physical activity, the CSEI self-esteem inventory. S. Coopersmith. Four tests of strength, speed, agility and flexibility were also conducted. The Eurofit European Physical Fitness Test was used. The results of the study by A. Kogut et al. show that BMI above the norm and physical activity have no effect on the quality of life of junior high school adolescents [Kogut 2017, 1, 14-23]. It is worth to pay attention to physical activity and its positive influence on health. Magdalena Madej et al. in their study „Wpływ aktywności ruchowej na wyrównanie zaburzeń przemiany materii u młodzieży licealnej” examined a group of 196 people, half of whom were those who do not engage in regular physical activity and the other half in which people engage in physical activity 3-4 times a week. In order to verify the effect of physical activity on metabolism, the authors used a lifestyle questionnaire, tissue bioimpedance analysis, waist and hip circumference measurement, and Martinet's fitness test for the study. Tissue bioimpedance analysis included data such as fat percentage and distribution, muscle percentage, water percentage, and bone mass content. The Martinet performance test involves measuring blood pressure and heart rate. The test subject is asked to perform 20-40 squats at a rate of 60 per minute. Then measurements are taken immediately after the exercise. Subsequent measurements are taken after 1 minute, 2 minutes, 3 minutes until the indices reach the resting level. The results of the study of M. Madej et al. show that in subjects who showed a better efficiency BMI, WHR and body fat percentage composition was lower [Madej 2018, 4, 102-111]. Noteworthy is the study by Magdalena Tyc et al. „Porównanie sprawności fizycznej zdrowych, niesłyszących i niewidomych uczniów w wieku 11-12 lat”. The authors examined a group of 69 children (32 girls, 37 boys), whose age ranged from 11 to 12 years. The subjects were divided into 3 groups. Group of healthy children ( 24 persons), group of deaf children (22 persons) and group of blind children (23 persons). In order to achieve the objectives of the study, the authors subjected children from all study groups to 5 tests testing their physical fitness: balance test, upper and lower limb muscle strength test, abdominal muscle strength test, and flexibility test. The first test, i.e. balance test, consisted of standing on one leg for one minute. The second 
test measured upper limb muscle strength by throwing a medicine ball. The third test measured lower limb strength by jumping from a standing position. The fourth test measured upper limb strength. The fourth test, i.e. abdominal strength, measured the maximum number of sit-ups that the participant was asked to perform in 30 seconds. The fifth test, flexibility, consisted in a forward bend of the trunk. The results of the study by M. Tyc et al. show worse physical fitness in students with disabilities. In the groups of deaf and blind children, deaf children showed higher physical fitness [Tyc 2017, 1, 56-63]. As part of prevention, the health status of the population should be monitored. Marek Woszczak et al. in the paper „Ocena poziomu wydolności fizycznej u licealistów klas I i II” examined a group of 70 patients (37 women, 33 men) aged 16 to 18 years. During the study the authors wanted to assess the influence of gender, age, place of residence and BMI on the level of physical fitness. They used a survey questionnaire to obtain information about gender, age, place of residence, and BMI. In order to assess the level of physical fitness, a modified Harvard test was used. It consisted A modified Harvard test was used to assess physical fitness levels. Women had to climb a $30 \mathrm{~cm}$ high step for 4 minutes and men had to climb a $40 \mathrm{~cm}$ high step for 5 minutes at a rate of 30 times per minute. Each subject's heart rate was measured before the test began, and then after the test, the subject was asked to sit in a chair and the following 3 heart rate measurements. The first measurement was taken after a minute of rest and lasted 30 seconds, then after a 30 second break the second measurement was taken which also lasted 30 seconds and after another break of 30 seconds a final third 30 second measurement was taken. The measurements were then substituted into a formula and conclusions were drawn based on the calculations. The results of the study by M. Woszczak et al. proved that gender, place of residence and BMI have no effect on physical fitness. However, with increasing age physical fitness was higher in the study group [Woszczak 2018, 2, 70-83]. Foot defects are a serious problem that begins as early as several years of age. Paulina Glowacka et al. in their paper „Wady stóp u uczniów klas pierwszych z terenu województwa śląskiego” examined a group of 30 children (15 girls, 15 boys) aged between 7 and 10 years. In order to evaluate the feet, the authors used a plantocontourogram, in which they considered the following 4 parameters: Clarke's angle index, Wejsflog "W" index, heel angle gamma and toe valgus angle alpha. The results of the study by P. Głowacka et al. indicated the influence of BMI on the increased value of the alpha angle and gamma angle. On the other hand, the authors observed a decreased Clarke's angle in the whole group of study participants. [Głowacka 2019, 2, 94-105]. It is worth noting the study by Sylwia Potępa et al. in their paper „Charakterystyka lateralizacji u dzieci w wieku 5-7 lat". The authors conducted a study on a group of 110 
children (55 girls and 55 boys) aged from 5 to 7 years. The authors used diagnostic tests to assess the lateralization of the subjects' bodies. They consisted of so-called free observation of eye, ear, upper limb and lower limb selection during motor activity. Potępa et al. concluded that the lateralization process in children aged between 5 and 7 years is not complete [Potępa 2019, 1, 60-69].

\section{SUMMARY}

The subject of physiotherapy in children presented in this paper is a very important element in the comprehensive management of child development. It should be remembered that many disease entities, which are already treated at the very beginning of their development, can prognose positively for the expected effects of therapy. It is reasonable to apply the so-called physioprophylaxis, which in a timely manner will be able to contribute to the detection of the first abnormalities among pediatric patients. Considering the nature of work with paediatric patients, it is very important to maintain the best possible cooperation between the parent and the physiotherapist as in most cases it is the parent who should continue certain elements of the therapy prescribed by the physiotherapist at home with the child. This leads to constant stimulation of the body and faster effects of the therapy. The diagnostic methods, prevention, treatment and other information presented in this paper are things that every physiotherapist should take into account in their work.

\section{CONCLUSION}

1. Physiotherapy has a very broad application in both therapy and prevention of children.

2. There should be more research on the use of virtual reality therapy in pediatric physiotherapy.

3. Regular and conscientious adherence to the specialist's recommendations is a very important element in therapy.

\section{REFERENCES}

Balewska-Juras Katarzyna, Cywińska-Wasilewska Grażyna. 2015. Ocena wyników neurokinezjologicznego usprawniania metoda odruchowej lokomocji wedlug Vojty, dzieci z zaburzeniami centralnej koordynacji nerwowej. „Fizjoterapia polska”. 4: 32-41. 
Głowacka Paulina, Przyłudzka Marcela. 2019. Wady stóp u uczniów klas pierwszych z terenu województwa śląskiego. „Fizjoterapia polska”. 2: 94-105.

Kilon Małgorzata, Ruszkiewicz Martyna, Raczkowski Jan. 2018. Ocena stanu funkcjonalnego dzieci z mózgowym porażeniem dziecięcym przy użyciu wybranych skal i testów. „Fizjoterapia polska". 4: 86-93.

Kogut Anna, Kiljański Marek. 2017. Badanie wpływu masy ciała oraz aktywności fizycznej na jakość życia młodzieży gimnazjalnej. „Fizjoterapia polska”. 1: 14-23.

Kuliński Włodzisław, Dulnik Barbara. 2019. Kinezyterapia w mózgowym porażeniu dziecięcym - aspekty kliniczne. „Fizjoterapia polska”. 3: 106-117.

Madej Magdalena, Śliwiński Zbigniew. 2018. Wpływ aktywności ruchowej na wyrównanie zaburzén przemiany materii u młodzieży licealnej. „Fizjoterapia polska”. 4: 102-111.

Matusiak-Wieczorek Ewelina, Małachowska-Sobieska Monika, Synder Marek. 2016. Wptyw hipoterapii na zdolność utrzymywania równowagi $w$ pozycji siedzacej wśród dzieci z mózgowym porażeniem. „Ortopedia Traumatologia Rehabilitacja”. 2: 165-175. (DOI: 10.56.04/15093492.1205024).

Potępa Sylwia, Czplińska Aleksandra, Salwach Alicja. 2019. Charakterystyka lateralizacji u dzieci w wieku 5-7 lat. „Fizjoterapia polska”. 1: 60-69.

Salwach Alicja, Czaplińska Aleksandra, Potępa Sylwia. 2019. Ocena równowagi u dzieci ze spectrum zaburzeń autystycznych w wieku 5-7 lat. „Fizjoterapia polska”. 1: 38-45.

Tyc Magdalena, Kiljański Marek. 2017. Porównanie sprawności fizycznej zdrowych, niestyszacych i niewidomych uczniów w wieku 11-12 lat. „Fizjoterapia polska”. 1: 56-63.

Woszczak Marek, Bogacz Katarzyna, Syrewicz Katarzyna. 2017. Ocena zróżnicowania poziomu otluszczenia ciała osób uprawiających piłkę ręczna klasach I, II i III gimnazjum w zależności od poziomu ich wytrenowania i sprawności fizycznej. „Fizjoterapia polska”. 4: 84105.

Woszczak Marek, Bogacz Katarzyna, Szczepanik Marcin. 2018. Ocena poziomu wydolności fizycznej u licealistów klas I i II. „Fizjoterapia polska”. 2: 70-83. 
Wysoczańska Emilia, Skrzek Anna. 2017. Wpływ terapii z wykorzystaniem nowoczesnych technologii na aktywność $i$ wytrzymałość dzieci z mózgowym porażeniem dziecięcym. „Fizjoterapia polska”. 2: 100-111. 